\title{
Discriminant Function Method of Selection in Vegetable Cowpea Genotypes
}

\author{
V. Sivakumar ${ }^{1 *}$, V.A. Celine ${ }^{2}$ and C. Venkata Ramana ${ }^{3}$ \\ ${ }^{1}$ HRS, Dr. YSR Horticultural University, Chintapalli, Visakhapatnam, A.P., India \\ ${ }^{2}$ Department of Olericulture, College of Agriculture, Vellayani, Kerala, India \\ ${ }^{3}$ HRS, Dr. YSR Horticultural University, Lam, Guntur, A.P., India \\ *Corresponding author
}

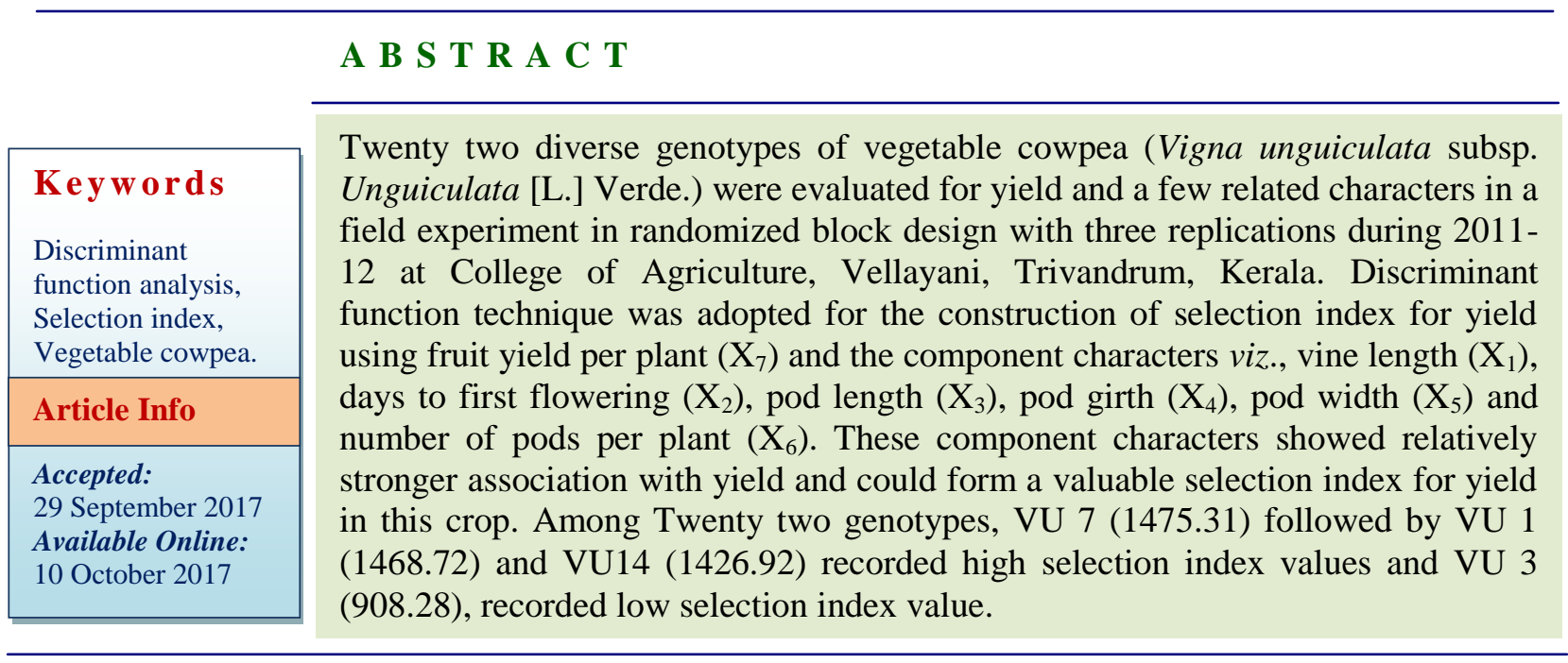

\section{Introduction}

Vegetable cowpea (Vigna unguiculata L. Walp) is one of the important food legumes and a valuable component of the traditional cropping systems in the semiarid tropics (Singh et al., 2002; Ayisi et al., 2000). The crop is adaptable to harsh environments and withstands extreme temperatures, water limiting conditions and poor soil fertility. It yields well in harsh environments where other food legumes do not thrive. Due to adaptation versatility, ability to fix atmospheric nitrogen and considerable level of seed protein, minerals and vitamin contents cowpea should significantly contribute as viable and alternative crop in low input farming systems.
The economic worth of a plant depends upon several characters so while selecting a desirable plant from a segregating population the plant breeder has to give due consideration to characters of economic importance. Selection index is one such method of selecting plants for crop improvement based on several characters of importance. This method was proposed by Smith (1947) using discriminant function of Fisher (1936). Smith suggested that a better way of exploiting genetic correlation with several traits having high heritability is to construct an index, called selection index, which combines information on all the 
characters associated with the dependent variable like yield. Thus selection index refers to a linear combination of characters associated with yield. The best known selection indices involve discriminant functions based on the relative economic importance of various characters. The discriminant function analysis measures the efficiency of various character combinations in selection. Selection index leads to simultaneous manipulation of several characters for genetic improvement of economic yield. This technique provides information on yield components and thus aids in indirect selection for the genetic improvement.

\section{Materials and Methods}

The experiment was carried out at Department of Olericulture, College of Agriculture, Vellayani $\left(8^{\circ} 5^{\prime} \mathrm{N}\right.$ latitude and $77^{\circ} 1$ ' E longitude at an altitude of $29 \mathrm{~m}$ above mean sea level) during 2011-2012 with 22 vegetable cowpea genotypes (Table 1). Soil type is a red loam belonging to Vellayani series, texturally classified as sandy clay loam. The trial was laid out in a randomized block design with three replications. Seeds were sown at a spacing of $45 \times 30 \mathrm{~cm}$. Timely crop management practices were adopted as recommended by Kerala Agricultural University (KAU, 2007) to raise healthy crop. Observations on growth, yield as well as yield contributing characters was noted on five randomly selected plants in each plot at different stages of the crop.

The selection index developed by Smith (1937) using discriminate function of Fisher (1936) was used to discriminate the genotypes based on all the characters.

The selection index is described by the function, $I=b_{1} x_{1}+b_{2} x_{2}+\ldots \ldots \ldots+b_{k} x_{k}$ and the merit of a plant is described by the function, $\mathrm{H}=\mathrm{a}_{1} \mathrm{G}_{1}+\mathrm{a}_{2} \mathrm{G}_{2}+\ldots \ldots \ldots+\mathrm{b}_{\mathrm{k}} \mathrm{G}_{\mathrm{k}}$ where $\mathrm{x}_{1}, \mathrm{x}_{2} \ldots \ldots \ldots \ldots \mathrm{x}_{\mathrm{k}}$ are the phenotypic values and $G_{1}, G_{2} \ldots \ldots \ldots \ldots G_{k}$ are the genotypic values of the plants with respect to characters, $\mathrm{x}_{1}, \mathrm{x}_{2} \ldots \ldots \ldots . . \mathrm{x}_{\mathrm{k}}$ and $\mathrm{H}$ is the genetic worth of the plant. It is assumed that the economic weight assigned to each character is equal to unity i. e., $\mathrm{a}_{1}$, $\mathrm{a}_{2} \ldots \ldots \ldots \ldots \mathrm{a}_{\mathrm{k}}=1$.

The regression coefficients (b) are determined such that the correlation between $\mathrm{H}$ and $\mathrm{I}$ is maximum. The procedure will reduce to an equation of the form, $\mathrm{b}=\mathrm{P}^{-1} \mathrm{Ga}$ where, $\mathrm{P}$ is the phenotypic variance-covariance matrix and $G$ is the genotypic variance-covariance matrix $\mathrm{x}$.

\section{Results and Discussion}

Discriminant function technique was adopted for the construction of selection index for yield using fruit yield per plant $\left(\mathrm{X}_{7}\right)$ and the component characters viz., vine length $\left(\mathrm{X}_{1}\right)$, days to first flowering $\left(\mathrm{X}_{2}\right)$, pod length $\left(\mathrm{X}_{3}\right)$, pod girth $\left(\mathrm{X}_{4}\right)$, pod width $\left(\mathrm{X}_{5}\right)$ and number of pods per plant $\left(\mathrm{X}_{6}\right)$. These component characters showed relatively stronger association with yield and could form a valuable selection index for yield in this crop.

The selection index, worked out in the present study is given below.

$\mathrm{I}=0.9566 \mathrm{X}_{1}+0.9798 \mathrm{X}_{2}+1.1151 \mathrm{X}_{3}+$ $1.9063 X_{4}+0.4786 X_{5}+0.6706 X_{6}+0.9003$ $\mathrm{X}_{7}$

The selection index value for each genotype was determined and they were ranked accordingly (Table 2). Five genotypes viz, VU 7 (1475.31), VU 1 (1468.72), $\quad$ VU14 (1426.92), VU 16 (1371.64) and VU 6 (1351.56) recorded high selection index values. Five génotypes viz, VU 3 (908.28), VU 24(939.50), VU 11 (952.97), VU 21 (1007.05), VU 10 (1148.04) recorded low selection index values. 
Identification of superior genotypes of vegetable cowpea based on discriminant function analysis was also done some workers.

In yard long bean, Resmi (1998) worked out the selection indices using thirteen characters and found that the genotype VS 6 had the maximum index value followed by VS 11 Superior genotypes were identified by constructing selection indices using the characters namely vine length, primary branches, petiole length, length and breadth of lateral leaflets, days to flowering, pod length, pod girth, pod weight, pods per inflorescence, pods per kilogram, pods per plant and yield.

Table.1 List of bush cowpea accessions used for the evaluation

\begin{tabular}{|c|c|l|l|}
\hline Sl. No. & Genotype Number & \multicolumn{1}{|c|}{ Genotype Name } & \multicolumn{1}{|c|}{ Source } \\
\hline 1 & VU 1 & Anaswara & College of Horticulture, Vellanikkara \\
\hline 2 & VU 2 & Local & Kollam \\
\hline 3 & VU 3 & Bhagyalakshmi & College of Agriculture, Vellayani \\
\hline 4 & VU 4 & Local & Haritha Agrofarm, Trivandrum \\
\hline 5 & VU 5 & Arka Suman & IIHR, Bangalore \\
\hline 6 & VU 6 & Arka Garima & IIHR, Bangalore \\
\hline 7 & VU 7 & Local & Thodupuzha \\
\hline 8 & VU 8 & Pusa Phalguni & IARI, New Delhi \\
\hline 9 & VU 9 & Co-26 & TNAU, Coimbatore \\
\hline 10 & VU 10 & Kanakamony & RARS, Pattambi, Palakkad \\
\hline 11 & VU 11 & Local & Kottamangalam, Ernakulam \\
\hline 12 & VU 13 & Local & College of Agriculture, Vellayani \\
\hline 13 & VU 14 & Local & College of Agriculture, Vellayani \\
\hline 14 & VU 15 & GC-9732 & RARS, Pattombi, Palakkad \\
\hline 15 & VU 16 & CO-2 & TNAU, Coimbatore \\
\hline 16 & VU 17 & Local & Brahmamangalam, Kottayam \\
\hline 17 & VU 18 & Local & College of Agriculture, Vellayani \\
\hline 18 & VU 19 & Local & Thrippunithura, Ernakulam \\
\hline 19 & VU 20 & Local & College of Agriculture, Vellayani \\
\hline 20 & VU 21 & GC-3 & College of Agriculture, Vellayani \\
\hline 21 & VU 22 & Local & Collicode, Kasargode of Horticulture, Vellanikkara \\
\hline 22 & VU 24 & Local & \\
\hline
\end{tabular}


Table.2 Vegetable cowpea genotypes ranked according to selection index

\begin{tabular}{|c|c|c|}
\hline Accession & Index & $\begin{array}{c}\text { Ranks in } \\
\text { ascending order }\end{array}$ \\
\hline VU 7 & 1475.31 & 1 \\
\hline VU 1 & 1468.72 & 2 \\
\hline VU 14 & 1426.92 & 3 \\
\hline VU 16 & 1371.64 & 4 \\
\hline VU 6 & 1351.56 & 5 \\
\hline VU 22 & 1350.27 & 6 \\
\hline VU 17 & 1333.83 & 7 \\
\hline VU 2 & 1290.76 & 8 \\
\hline VU 8 & 1265.53 & 9 \\
\hline VU 4 & 1257.67 & 10 \\
\hline VU 18 & 1241.98 & 11 \\
\hline VU 13 & 1207.84 & 12 \\
\hline VU 19 & 1198.24 & 13 \\
\hline VU 5 & 1196.97 & 14 \\
\hline VU 9 & 1184.4 & 15 \\
\hline VU 15 & 1158.91 & 16 \\
\hline VU 20 & 1152.57 & 17 \\
\hline VU 10 & 1148.04 & 18 \\
\hline VU 21 & 1007.05 & 19 \\
\hline VU 11 & 952.97 & 20 \\
\hline VU 24 & 939.5 & 21 \\
\hline VU 3 & 908.28 & 22 \\
\hline
\end{tabular}

(Based on discriminant function analysis)

Philip (2004) worked out selection indices for 50 genotypes of cowpea on the basis of pods per plant, number of inflorescence per plant, pods per inflorescence, pod length, seeds per pod and 100 seed weight.

Five superior genotypes were selected for hybridization programme as female parents to develop $\mathrm{F}_{1}$ hybrids.

Selection index for the genotype was computed based on the nine characters having significant genotypic correlation coefficients namely pods per cluster, pods per plant, pod yield per plant, pod weight, pod length, pod breadth, seeds per pod, length of harvest period and main stem length. The maximum selection index value was obtained for VS 41, while the least value was for VS 7 by Lovely (2005).

Manju (2006) observed selection indices involving the characters, peduncle length, pod length, pod girth, pod weight, pods per plant, seeds per pod, 100 seed weight, number of harvests, pod protein and yield per plant. Based on selection index, VS 27 ranked first followed by VS 8 and VS 19.

Discriminant function technique involves development of selection criteria on a combination of various characters and aids the breeder in indirect selection for genetic improvement in yield. In plant breeding, selection index refers to a linear combination of characters associated with yield. 


\section{Acknowledgments}

The authors are highly grateful to the Department of Olericulture, College of Agriculture, Kerala Agricultural University, Vellayani, Thiruvananthapuram, Kerala for providing all necessary materials to carry out the present study.

\section{References}

Ayisi, K. K., Nkgapele, R. J. and Dakora, F, D. 2000. Nodule formation and function in six varieties of cowpea (Vigna unguiculata L. Walp.) grown in a nitrogen rich soil in South Africa. Symbiosis 28:17-31.

Lovely, B., 2005. Genetic analysis of yield and mosaic resistance in yard long bean [Vigna unguiculata subsp. sesquipedalis (L.) Verdc.). Ph.D. thesis, Kerala Agricultural University, Thrissur, 147p.

Manju, P. R., 2006. Characterization of vegetable cowpea (Vigna unguiculata (L.) Walp.). Ph.D. thesis, Kerala Agricultural University, Thrissur, 147p.
Philip, M. C. A., 2004. Genetic analysis of legume pod borer Maruca vitrata (Fab.) resistance and yield in cowpea (Vigna unguiculata (L.) Walp.). PhD thesis, Kerala Agricultural University, Thirssur, 171p.

Resmi, P. S., 1998. Genetic variability in yard long bean (Vigna unguiculata subsp. sesquipedalis (L.) Verdcourt.). MSc (Ag) thesis, Kerala Agricultural University, Thrissur, 94p.

Singh, B. B., Ehlers, J. D., Sharma, B. and Freire-Filho, F. R. 2002. Recent progress in cowpea breeding. In: Fatokun, C. A., Tarawali, S. A., Singh, B. B., Kormawa, P. M. and Tamo, M. (eds) Proceedings, world cowpea conference III, challenges and opportunities for enhancing sustainable cowpea production. IITA, Ibadan, Nigeria, pp 22-40.

Smith, F. H., 1937. A discriminate function for plant selection. Ann. Eugen. 7: 240250.

\section{How to cite this article:}

Sivakumar, V., V.A. Celine and Venkata Ramana, C. 2017. Discriminant Function Method of Selection in Vegetable Cowpea Genotypes. Int.J.Curr.Microbiol.App.Sci. 6(10): 4954-4958. doi: https://doi.org/10.20546/ijcmas.2017.610.469 